\section{STUDIES ON THE BIOAVAILABILITY OF SOME NEW ERYTHROMYCIN ESTERS}

\author{
Leone Dall'Asta, Andrea Comini, \\ Eugenio Garegnani, Dario Alberti, \\ Germano CoPPI and GiusePPe QuAdro \\ Research Laboratories, Proter Spa, \\ I-20090 Opera, Milan, Italy
}

(Received for publication May 26, 1987)

Erythromycin has acquired renewed significance because of its activity against chlamydia', 2), chancroid ${ }^{33}$, Mycoplasma pneumoniae $^{4)}$, whooping cough ${ }^{5,8)}$ and legionnaires' disease $^{\text {7) }}$.

To avoid inactivation of erythromycin by the low gastric $\mathrm{pH}$ after oral intake, entero-soluble formulations have been designed and several esters or salts of erythromycin have been prepared. Commonly used oral forms of erythromycin are erythromycin base as entero-soluble tablets, erythromycin stearate, ethylsuccinate and estolate.

In this paper we report the synthesis and bioavailability in rats of nine erythromycin esters in comparison with some established erythromycin derivatives.

The esters were prepared by treatment of erythromycin $\mathrm{A}$ in acetone with 1.25 equivalent of pivaloyloxymethylsuccinoyl chloride, 2-, or 3-, or 4-fluorobenzoyl chloride, 3,4-dimethoxybenzoyl chloride, 3,4-methylenedioxybenzoyl chloride, 3,4,5-trimethoxybenzoyl chloride, 2thiophencarbonyl chloride or 1-adamantanecarbonyl chloride respectively, in the presence of an excess of $\mathrm{NaHCO}_{3}$. After dilution with buffer solution ( $\mathrm{pH} 7$ ), the esters were obtained as white crystals.

The bioavailabilities in rats of the nine esters were compared to those of three standard derivatives by measuring the plasma levels and the urinary excretions after oral administration of the compounds in doses equivalent to 100 $\mathrm{mg} / \mathrm{kg}$ of erythromycin base. Wistar rats (average weight $250 \mathrm{~g}, 20$ animals per compound), fasting for 12 hours before the experiments, were used. Four rats were sacrificed respectively $1,2,3$ and 5 hours after the oral administration of each of the twelve compounds in $5 \%$ gum arabic $(20 \mathrm{ml} / \mathrm{kg})$. Four rats were restrained in opposite cages to collect the urine from 0 to 24 hours after the compounds' ad-

Table 1. Plasma levels, $\mathrm{AUC}_{0 \sim 5 \text { hours }}$, urinary excretions of erythromycin base in rats after oral administration of erythromycin esters in doses equivalent to $100 \mathrm{mg} / \mathrm{kg}$ as base.

\begin{tabular}{|c|c|c|c|c|c|c|}
\hline \multirow{2}{*}{ Erythromycin ester } & \multicolumn{4}{|c|}{$\begin{array}{l}\text { Plasma levels }(\mu \mathrm{g} / \mathrm{ml}) \\
(\text { mean } \pm \mathrm{SE})\end{array}$} & \multirow{2}{*}{$\begin{array}{c}\mathrm{AUC}_{0 \sim 5 \text { hours }} \\
(\mu \mathrm{g} / \mathrm{ml} \cdot \\
5 \text { hours })\end{array}$} & \multirow{2}{*}{$\begin{array}{c}\text { Urinary } \\
\text { excretion } \\
(0 \sim 24 \text { hours) } \\
(\text { mean }+ \\
\text { SE, } \%)\end{array}$} \\
\hline & 1 hour & 2 hours & 3 hours & 5 hours & & \\
\hline $\begin{array}{l}\text { Pivaloyloxymethyl- } \\
\text { succinate (1) }\end{array}$ & $0.48 \pm 0.19$ & $0.18 \pm 0.03$ & $0.14 \pm 0.02$ & $0.09 \pm 0.02$ & 0.96 & $0.19 \pm 0.04$ \\
\hline 2-Fluorobenzoate (2) & $0.31 \pm 0.01$ & $0.31 \pm 0.04$ & $0.27 \pm 0.01$ & $0.18 \pm 0.01$ & 1.20 & $0.88 \pm 0.03$ \\
\hline 3-Fluorobenzoate (3) & $0.11 \pm 0.01$ & $0.08 \pm 0.01$ & $0.10 \pm 0.01$ & $0.04 \pm 0.01$ & 0.38 & $0.15 \pm 0.01$ \\
\hline 4-Fluorobenzoate (4) & $0.12 \pm 0.01$ & $0.08 \pm 0.01$ & $0.08 \pm 0.02$ & $0.10 \pm 0.03$ & 0.47 & $0.12 \pm 0.01$ \\
\hline 3,4-Dimethoxybenzoate (5) & $0.45 \pm 0.08$ & $0.24 \pm 0.05$ & $0.11 \pm 0.05$ & $0.17 \pm 0.02$ & 1.02 & $1.16 \pm 0.07$ \\
\hline $\begin{array}{l}\text { 3,4-Methylenedioxy- } \\
\text { benzoate ( } 6)\end{array}$ & $0.12 \pm 0.01$ & $0.14 \pm 0.03$ & $0.10 \pm 0.02$ & $0.07 \pm 0.01$ & 0.48 & $0.35 \pm 0.01$ \\
\hline $\begin{array}{l}\text { 3,4,5-Trimethoxy- } \\
\text { benzoate }(7)\end{array}$ & $1.51 \pm 0.06$ & $1.50 \pm 0.13$ & $1.33 \pm 0.08$ & $0.67 \pm 0.05$ & 5.67 & $2.13 \pm 0.40$ \\
\hline 2-Thiophencarboxylate (8) & $0.13 \pm 0.01$ & $0.23 \pm 0.03$ & $0.12 \pm 0.01$ & ND & 0.07 & $0.18 \pm 0.02$ \\
\hline $\begin{array}{l}\text { 1-Adamantanecarboxylate } \\
\text { (9) }\end{array}$ & $0.23 \pm 0.07$ & $0.17 \pm 0.02$ & $0.15 \pm 0.03$ & ND & 0.62 & $0.23 \pm 0.03$ \\
\hline Stearate (salt) & $1.91 \pm 0.21$ & $1.67 \pm 0.10$ & $1.46 \pm 0.19$ & $0.52 \pm 0.02$ & 6.29 & $2.02 \pm 0.28$ \\
\hline Estolate & $1.61 \pm 0.25$ & $1.34 \pm 0.25$ & $1.38 \pm 0.13$ & $0.58 \pm 0.05$ & 5.60 & $2.30 \pm 0.21$ \\
\hline Ethylsuccinate & $0.52 \pm 0.03$ & $0.35 \pm 0.02$ & $0.33 \pm 0.01$ & $0.14 \pm 0.01$ & 1.51 & $0.94 \pm 0.13$ \\
\hline
\end{tabular}

a Four animals/time.

ND: Not determinable $(<0.04 \mu \mathrm{g} / \mathrm{ml})$. 
Table 2. Lung levels of erythromycin base in rats after oral administration of erythromycin esters in dose equivalent to $100 \mathrm{mg} / \mathrm{kg}$ as base.

\begin{tabular}{lll}
\hline \multirow{2}{*}{$\begin{array}{c}\text { Erythromycin } \\
\text { ester }\end{array}$} & \multicolumn{2}{c}{$\begin{array}{c}\text { Lung levels } \\
(\mu \mathrm{g} / \mathrm{g} \text { of fresh tissue) } \\
\text { (mean } \pm \text { SE) }\end{array}$} \\
\cline { 2 - 3 } & 90 minutes & 180 minutes \\
\hline $\begin{array}{l}\text { Stearate (salt) } \\
\text { Estolate }\end{array}$ & $15.26 \pm 1.86$ & $13.17 \pm 1.77$ \\
$\begin{array}{l}\text { 3,4,5-Trimethoxy- } \\
\text { benzoate }\end{array}$ & $26.10 \pm 2.28$ & $28.11 \pm 1.92$ \\
\hline
\end{tabular}

a Four animals/time.

ministration. Plasma and urinary levels were assayed for erythromycin base by an agardiffusion method using Micrococcus luteus ATCC 9341 as the assay organism ${ }^{82}$. This method measures only erythromycin base; all esters in our experimental conditions were inactive. Area under the curve (AUC) was calculated according to the trapezoidal rule.

Table 1 reports the plasma levels, the $\mathrm{AUC}_{0 \sim 5 \text { nours }}$ and the urinary excretions of the new nine esters in comparison with the three commonly used erythromycin derivatives.

The most interesting ester is the 3,4,5-trimethoxybenzoate (7) with a bioavailability similar to those of stearate and estolate.

The 3,4-dimethoxybenzoate (5) and the 2fluorobenzoate (2) show a bioavailability similar to that of ethylsuccinate.

In order to investigate the lung levels of erythromycin base, four rats were sacrificed respectively at 90 and 180 minutes after the oral administration of 7 , stearate and estolate esters. The lungs were homogenized in phosphate buffer $0.1 \mathrm{M}, \mathrm{pH} 8.0$ and the antibiotic lung levels were assayed as previously described.

The Table 2 shows that the 3,4,5-trimethoxybenzoate ester allows to obtain lung levels of erythromycin base higher than that of the other two standard esters.

\section{Experimental}

Erythromycin pivaloyloxymethylsuccinoyl ester was prepared by the reaction of erythromycin A $(17.3 \mathrm{~g})$ in acetone $(100 \mathrm{ml})$ at $20 \sim 25^{\circ} \mathrm{C}$ with pivaloyloxymethylsuccinoyl chloride $(7.53 \mathrm{~g})$ in the presence of $\mathrm{NaHCO}_{3}(10 \mathrm{~g})$. After stirring at the same temperature for 6 hours, the reaction mixture was poured into phosphate buffer $(\mathrm{pH}$
7.0); the precipitate was filtered and dried under vacuum at $35^{\circ} \mathrm{C}$ to afford $1(19.6 \mathrm{~g})$. MP $116 \sim 119^{\circ} \mathrm{C}$ (dec); $[\alpha]_{\mathrm{D}}^{20}-73.5^{\circ}$ (c 2, EtOH). Erythromycin A, determined after enzymatic or chemical hydrolysis of the ester by reversedphase liquid chromatography (Lichrosorb RP 18 $10 \AA$ ) using acetonitrile $-0.2 \mathrm{M}$ ammonium acetate - water $(65: 10: 30)(\mathrm{pH} \mathrm{7.0)}$ as the mobile phase (detection UV $215 \mathrm{~nm}$ ) ${ }^{92}$ was $71.3 \%$.

By a method similar to that described for the synthesis of 1, were prepared: Erythromycin 2fluorobenzoate (2) $\mathrm{mp} 141 \sim 144^{\circ} \mathrm{C}$ (dec), $[\alpha]_{\mathrm{D}}^{20}$ $-72.8^{\circ}$ ( c 2, EtOH); 3-fluorobenzoate (3) $\mathrm{mp}$ $131 \sim 135^{\circ} \mathrm{C}$ (dec), $[\alpha]_{\mathrm{D}}^{20}-72.6^{\circ}$ (c 2, EtOH); 4-fluorobenzoate (4) $\mathrm{mp} \quad 123 \sim 126^{\circ} \mathrm{C}, \quad[\alpha]_{\mathrm{D}}^{20}$ $-72.6^{\circ}$ (c 2, EtOH); 3,4-dimethoxybenzoate (5) $\operatorname{mp} 123 \sim 124^{\circ} \mathrm{C},[\alpha]_{\mathrm{D}}^{20}-70.9^{\circ}$ (c 2, EtOH); 3,4methylenedioxybenzoate (6) $\mathrm{mp} 125 \sim 128^{\circ} \mathrm{C}$, $[\alpha]_{\mathrm{D}}^{20}-74.5^{\circ}$ (c 2, EtOH); 3,4,5-trimethoxybenzoate $(7) \mathrm{mp} 172 \sim 175^{\circ} \mathrm{C}(\mathrm{dec}),[\alpha]_{\mathrm{D}}^{20}-73^{\circ}$ (c 2, EtOH); 2-thiophencarboxylate (8) $\mathrm{mp}$ $146 \sim 148^{\circ} \mathrm{C},[\alpha]_{\mathrm{D}}^{20}-74.1^{\circ}$ (c 2, EtOH); $1-$ adamantanecarboxylate (9) $\mathrm{mp} 105 \sim 109^{\circ} \mathrm{C}$, $[\alpha]_{\mathrm{D}}^{20}-14.1^{\circ}$ ( c 2, EtOH).

\section{References}

1) Csango, P. A.; T. Gundersen \& G. Annestad: Double-blind comparison of erythromycin and doxycycline therapy for nongonococcal urethritis. Proceeding of the 5th International Symposium on Human Chlamydial Infection. Ed., N. MARD et al., pp. 65 71, Elsevier North Holland, New York, 1982

2) Lassus, A.; J. Pafyonen, M. Kousa \& P. SAIKKU: Erythromycin and lymecycline treatment in Chlamydia-positive and Chlamydianegative non-gonococcal urethritis. A partnercontrolled study. Acta Derm. Venereo1. 59: $278 \sim 281,1979$

3) Carpenter, J. L.; A. Back, D. Gehle \& T. OBERHOFFER: Treatment of chancroid with erythromycin. Sex. Transm. Dis. 8: 192 197, 1981

4) Shames, J. M.; R. B. George, W. B. Holliday, J. R. Rasch \& W. J. MogabGab: Comparison of antibiotics in the treatment of mycoplasmal penumonia. Arch. Intern. Med. 125: 680 684, 1970

5) MORSE, S.I.: Whooping cough in infectious diseases. In A Modern Treatise of Infectious Processes. 2nd Ed. Ed., P. D. HoEPRICH, pp. $277 \sim 280$, Harper \& Row, Hagerstown, 1977

6) Trollfors, B.: Effects of erythromycin and amoxycillin on Bordetella pertussis in the naso- 
pharynx. Infection 6: 228 230, 1978

7) BAINE, W. B.: Clinical manifestations of Legionnaires' disease and recommended therapy. In Legionnaires. The Disease, the Bacterium and Methodology. Eds., G. L. Jones \& G. A. Herbert, pp. 4 8, U.S. Dept. of Health, Education and Welfare, Public Health Service, Atlanta, 1978
8) Kavanagh, F. \& L. J. Dennin: Erythromycin. In Analytical Microbiology. Ed., F. KAVANAGH, pp. 289 294, Academic Press, New York, 1963

9) Tsuji, K. \& J. F. GoETz: Elevated column temperature for the high-performance liquid chromatography determination of erythromycin and erythromycin ethylsuccinate. J. Chromatogr. 157: 185 196, 1978 